\title{
DIVERSITY OF LEGAL TRADITIONS AND INTERNATIONAL LAW: KEYNOTE ADDRESS
}

\author{
Abdulqawi Yusuf
}

\section{Keywords}

Diversity, legal tradition, International Court of Justice

\begin{abstract}
Judge Abdulqawi Yusuf delivered the Keynote Address of the Second Annual CJICL Conference on Saturday 18 May 2013 at the Faculty of Law of the University of Cambridge. The Address was made possible due to the generous sponsorship of Brill-Martinus Nijhoff.
\end{abstract}

\section{Introductory remarks}

I was pleasantly surprised by the title of your conference: 'Legal traditions in a diverse world'. Your positive outlook on the endurance of the diversity of legal traditions, which is the way I read the title of the conference, is encouraging. Diversity is a value to be cherished and protected in all realms of human endeavour, as well as in nature, customs and cultures. But my question to you is this: can we take for granted the continued diversity of legal traditions, or do we have to fight for their survival in a globalizing world? If we have to fight for diversity, is it worthwhile doing so? I will return to these questions a bit later, but let me tell you first why I am raising them.

I am raising these questions for two reasons. First, I have spent a part-maybe a small one, but nevertheless an important part-of my professional life on the preservation and protection of diversity through the law. My first experience was as a participant to the UN conference on biological diversity, whose task was to write a convention that would help save genetic resources, animal and plant species, as well as ecosystems, from human destruction. That convention was concluded and has been in operation for almost exactly 20 years, having entered into force in December 1993. ${ }^{1}$ My second experience was in UNESCO,

\footnotetext{
* Judge, International Court of Justice. The author wishes to thank Ms. Ciara Murphy and Mr. Antoine Ollivier for their invaluable research assistance.

1 United Nations Convention on Biological Diversity, 5 June 1992, 1760 UNTS 79.
}

Copyright $\odot$ the Author(s).

This work is licensed under a Creative Commons Attribution-NonCommercial-NoDerivs 3.0 License. 
where I had to advise on the elaboration of a convention on cultural diversity, whose main objective was to safeguard cultural traditions and expressions against homogenisation in the context of globalization. Here, the task was to identify tools in the law and legal traditions of various countries, which could protect an important diversity that was considered to be under threat. Again, a convention was concluded and came into force in $2007^{2}$

The second reason is that I received my initial training as a lawyer in one of the most diverse legal systems in the world. Somalia's mixed legal system includes civil law, common law, customary law, and Islamic law. I feel that this diversity has been of great help in my work in international law. For example, I find a lot of similarities between the Somali customary law, or Xeer (pronounced 'Heer'), and international law. Xeer is a decentralised system designed to regulate relations among and within clan families or clan coalitions, and although it borrows from the other legal traditions and systems, it modifies them and adapts them to its own design. Thus, for example, in a case decided by the Somali Supreme Court in 1964, the Court said the following about the relationship between Sharia law and customary law in Somalia:

Sharia law as applied in the Somali Republic has been modified in certain respects by customary law. First, even though the spread of Islam among the Hamitic tribes put an Islamic gloss upon the customary organization existing in the country, it did not produce any effective change in the tribal customs relating to compensation of damages. ${ }^{3}$

Of particular relevance to my current occupation is the judicial system in the Somali Xeer. It is based on the consent of the parties. I do not, therefore, find it singular that the jurisdiction of our Court is similarly based on the consent of the parties. The composition of the Xeer court varies depending on whether the elders nominated to sit on the bench are from the respective clans of the opposing parties, or whether they are from third-party clans. If they are from the same clans as the parties, and nominated by them, they have to be equal in numbers from each side. That will remind you, I am sure, of arbitration at the international

${ }^{2}$ UNESCO Convention on the Protection and Promotion of the Diversity of Cultural Expressions, 20 October 2005, 2440 UNTS 311.

${ }^{3}$ Hussein Hersi and Ahmed Aden v Yusuf Deria Ali (Civil Appeal No 2 of 1964), Supreme Court of Somalia, 16 May 1964 quoted in P Contini, The Somali Republic: An experiment in Legal Integration (1969). 
level. However, in this case the decision must be adopted by consensus. If, instead, the elders come from a third-party, their number has simply to be uneven in order to allow them to adopt their decisions by majority vote-exactly as we do at the Court. Thus, one could say that I am an elder sitting on a third-party Xeer Court, which happens to deal with international law, instead of Somali customary law.

\section{Diversity of legal traditions and international law}

In light of the theme of your conference, the question I would like to address is: what role do legal traditions play in the creation and application of international law? To what extent does international law draw on legal traditions? Is it derived from only some or from most of the many legal traditions of the world?

It is not a paradox to say that the universality of international law depends on diversity. Indeed, in the case of international law, universalisation and globalization do not reduce diversity; they actually promote it. For international law, universalisation means borrowing and adapting concepts and principles from different legal traditions. Thus, diversity plays a different role in international law. The more international law can draw on multiple legal traditions, the more universal it will be considered. International law was, in its origins, based on uniformity and homogeneity, and thus diversity allows it to break out of those bounds.

The legitimacy of international law also depends, to a great extent, on its ability to represent diverse legal traditions. As observed by Georges Abi-Saab:

If we really want international law to take hold and be taken seriously by all, it has to be, both in its creation and in its interpretation and application, the product of the community as a whole, reflecting, by synthesis or symbiosis, the legal visions, needs and aspirations of all the components of this community. ${ }^{4}$

As we all know, international law has not always drawn inspiration from a variety of legal systems. Many international law textbooks inform us that the origins of contemporary international law are to be found in the Jus Publicum Europaeum

${ }^{4}$ G Abi-Saab, 'The Portrait of the Jurist as an international Judge', in C Peck \& R S Lee (eds), Increasing the Effectiveness of the International Court of Justice: Proceedings of the ICJ/UNITAR Colloquium to Celebrate the 50th Anniversary of the Court (1997) 171, quoted in K Keith, 'International Court of Justice: Reflections on the Electoral Process' (2010) 9 Chinese J Int'l L 49, 66. 
and that in its early development little use was made of legal systems other than Roman civil law and Anglo-Saxon common law. There is some truth to that assertion, but that is not because other peoples and nations outside Europe were incapable of producing international legal rules, or because they did not have such legal rules.

Rather, in the $19^{\text {th }}$ century, European states, which happened to be the most powerful nations during that period of human history, formed themselves into a sort of club of 'founders' which arrogated to itself the right to admit other members to the family of nations to whom international law would be applicable. These $19^{\text {th }}$ century European nations and those among their legal scholars who supported the colonial/imperial designs of their countries, used, inter alia, two fundamental concepts to exclude others from the family of nations: constitutive recognition (according to which a foreign state would not be considered sovereign and independent unless it received a 'birth certificate' from the European powers) and a subjectively defined 'standard of civilization' (according to which those who did not belong to the same religious faith and civilization as the European powers, were considered barbarian, and beyond the pale of the law of nations). Oppenheim, for example, tells us that as late as the First World War:

[T] he position of States such as Persia, Siam, China, Abyssinia, was to some extent anomalous. Although there was considerable international intercourse between these States and States of Western civilization, there was a question of how far relations with their governments could usefully be based upon the rules of international society, since they belonged to ancient but different civilizations. ${ }^{5}$

He could have added Japan, the Ottoman Empire, Morocco, and the Indian and African states with which the European powers concluded treaties, but which they still excluded from the realm of international law.

This position was adopted by the European powers to find a philosophical justification for the colonial enterprise. We all know how much colonialism, and its contempt for the traditions and civilizations of the peoples of other continents-as well as the treatment of their territories as terra nullius-has contributed to oppression and human rights violations in the colonized countries. The public law of Europe of the time, and the theories and writings of its scholars

5 R Jennings \& A Watts (eds), Oppenheim's International Law, Volume 1, Peace $\left(9^{\text {th }}\right.$ ed, 1997) 89. 
who provided a legal justification for colonization, played a prominent role in this state of affairs, and there is no denying it. But that is not the subject of our talk today.

The question here is, instead: when did the public law of Europe begin to change into international law? And when did international law start to universalise and to enrich itself with the legal traditions of all nations? Different scholars will perhaps place this at different periods in the early part of the $20^{\text {th }}$ century; but my own answer is that the public law of Europe gradually metamorphosed into international law with the creation of international organizations such as the League of Nations, the International Labour Organization (ILO) and the Permanent Court of International Justice (PCIJ). This does not mean that international law was immediately enriched with the traditions of non-European nations-as late as the mid-30s, when Mussolini invaded Ethiopia, one of Italy's main arguments before the Council of the League of Nations was that Ethiopia, as much as it may claim to be an old Christian nation, could not be considered as a civilized nation and was consequently beyond the pale of international law. But the first seeds of change were planted in the constitutive instruments of those organizations, and in the Statute of the PCIJ, of which I will give you some examples shortly. These universalist seeds were also planted due to the participation in those organizations of the newly-independent Latin American Republics, some Asian countries such as China, Siam (now Thailand) and Japan, and a couple of African states, namely Ethiopia and Liberia.

These seeds were to bear fruit later with the elaboration and adoption of the UN Charter and the universal declaration on human rights. It is indeed with the adoption of the San Francisco Charter and the creation of the UN system that, in my view, we can really speak of the universal vocation of international law.

Finally, with the advent of decolonization and the consequent emergence of over one hundred newly independent states onto the global stage, it may be said that the real universalisation of international law started in earnest. International law became truly universal. This was, however, a gradual and slow process. Scholars from the Third World began to criticise the orthodox theories of international law, such as the doctrines propounded by Martens, Wheaton, Westlake, Hall and Liszt, and later Oppenheim and Fauchille, which maintained that international law was entirely developed through treaty and custom by the Christian states of Europe.

These Third World scholars started writing more and more about international law in the 1960s, bringing their own historiography, culture, and legal traditions to bear on the concepts and norms of international law. They spoke of 
the contribution of Buddhism, ${ }^{6}$ Islamic doctrine, ${ }^{7}$ Confucianism, ${ }^{8}$ Hinduism, ${ }^{9}$ and the 'Afro-Asian' states to international law in lectures delivered at the Hague Academy of International Law or in their own scholarly publications, ${ }^{10}$ as the Third World found its voice in the aftermath of decolonization in the 1950s and 1960s. As evidence that international law did not exist only in Europe, they pointed to the existence of regulated international legal and commercial relations between, for example, the Afro-Asian states and foreign governments, and of treaties concluded between kingdoms in those continents.

However, in some western legal circles there was not only fear, but also resistance to the views and positions of Third World scholars and governments. For example, in 1972, Sir Gerald Fitzmaurice prepared a special report on the future of international law for the 1973 Centenary Session of the Institute of International Law. ${ }^{11}$ In this report, he affirmed that one of the threats posed to international law was the lack of acceptance by the newly independent states of the rules of international law as they had been developing until that time. ${ }^{12}$ He also strongly criticised some of the concepts proposed by Third World authors and governments, such as the right of peoples to self-determination, ${ }^{13}$ the patrimonial sea, ${ }^{14}$ and permanent sovereignty over natural resources. ${ }^{15}$

Others were more open-minded and, I would say, more enlightened. I would most notably refer here to Bernard V A Röling, whose remarkable 1960 book entitled International Law in an Expanded World advocated the evolution of a 'New World Law' consonant with the new sociological structure of the international community of nations. In the introduction to his book, Röling stated, inter alia, that 'law is not constant in a community, but a function ... it ought to change with changes in views, interests and power relations. ${ }^{16}$ In his view, the traditional

\footnotetext{
6 K N Jayatilleke, 'The principles of international law in Buddhist doctrine' (1967) 120 RdC 441.

7 R Mahmassani, 'The principles of international law in the light of Islamic doctrine' (1966) $117 \mathrm{RdC}$ 201.

8 K Iriye, 'The principles of international law in the light of Confucian doctrine' (1967) 120 RdC 1.

9 K R R Sastry, 'Hinduism and international law' (1966) 117 RdC 503.

${ }^{10} \mathrm{~T}$ O Elias, Africa and the Development of International Law (2 ${ }^{\text {nd }}$ edn, 1988); R P Anand (ed), Asian States and the Development of Universal International Law (1972).

${ }^{11}$ G Fitzmaurice, 'The Future of Public International Law and the International Legal System in the Circumstances of Today', in Institut de Droit International, Livre du centenaire 1873-1973: évolution et perspectives du droit international (1973) 196.

12 Ibid, 205-13, 224-28, 239-45 and 251-54.

${ }^{13}$ Ibid, 232-35.

${ }^{14}$ Ibid, 217-19.

15 Ibid, 228-230.

${ }^{16}$ B V A Röling, International law in an expanded world (1960), x.
} 
law of nations had to change before it could act as the binding element in a world community, and a 'continuous struggle must be waged for the new law.' ${ }^{17}$ Similarly, Judge Robert Jennings, in an article published in the 1980s, observed that it was imperative to 'develop international law to comprehend within itself the rich diversity of cultures, civilizations and legal traditions'; according to him:

[t]he first and essential general principle of public international law is its quality of universality; that is to say, that it be recognized as a valid and applicable law in all countries, whatever their cultural, economic, socio-political, or religious histories and traditions. International law must now develop and change to make it more suited to the new and global community of states. ${ }^{18}$

The fears of Fitzmaurice never materialised, and the rules and concepts put forward by the newly independent states gradually found their way into general international law, thus enabling it to acquire a more universal outlook reflective of a diverse international community.

\section{The ICJ and the diversity of legal traditions}

Having made this brief excursion into the evolution of international law and its relationship to legal traditions, I would like to focus on how the International Court of Justice, the principal judicial organ of the United Nations, incorporates and accommodates the diversity of legal traditions into its jurisprudence. How and to what extent has the Court enabled international law to change and to accommodate the profoundly different international community, which exists today, and through what means and methods? If 'international law, like all law, must change with the changing circumstances', ${ }^{19}$ how has international law adjusted to reflect and incorporate the diversity resulting from the legal traditions and systems of numerous new states? What is the role of the Court in this context?

I would argue that the Court has played and continues to play an active role in this regard. Legal diversity and the differences between legal systems were among the early seeds planted by the drafters of the Statute of the PCIJ in order

\footnotetext{
17 Ibid.

${ }^{18}$ R Y Jennings, 'Universal International Law in a Multicultural World' in M Bos \& I Brownlie (eds), Liber Amicorum for the Rt. Hon. Lord Wilberforce (1987), 40.

${ }^{19}$ R P Anand, 'Changing Dimensions of International Law: An Asian Perspective' (2006) 1 Collected Courses of the Xiamen Academy of International Law 15, 49.
} 
to introduce an element of universality into its mission; this is very important because, as you know, the Statute then served as the blue print for the ICJ's own Statute. Although their conception of diversity was certainly more limited than ours today, the drafters sought to accommodate and incorporate diversity in the PCIJ Statute through three provisions in particular:

1. Article 9, which states that the Court's bench must represent the principal legal systems and main forms of civilization;

2. the possibility to append separate and dissenting opinions to the Court's judgments, provided for under Article 57; and

3. the designation of the 'general principles of law recognized by civilized nations' as a source of international law in Article 38, paragraph (1)(c) of the Statute.

I will examine each of these provisions before concluding with a few reflections on the gradual movement of international law to a universal international law whose development needs to receive continuous inputs and contributions from various parts of the world and from diverse legal systems and traditions.

\subsection{Judges representing the 'main forms of civilization' and the 'principal legal systems of the world'}

I observed earlier, quoting from Georges Abi-Saab, that in order to be considered universal, international law must be a product of the community, and a synthesis and symbiosis of its legal traditions. In the same vein, the ICJ must, again in the words of Georges Abi-Saab, ensure that it is 'not dominated by the legal or social culture or special interests of any segment thereof', especially 'if it wants to be taken seriously as a World Court ... universalist in its composition, outlook and vocation, truly representing and at the service of the international community in its entirety. ${ }^{20}$

Let us begin with the composition of the Court. Article 2 of the Statute of the ICJ provides that:

The Court shall be composed of a body of independent judges, elected regardless of their nationality from among persons of high

\footnotetext{
${ }^{20} \mathrm{G}$ Abi-Saab, 'The International Court as a world court', in V Lowe \& M Fitzmaurice (eds), Fifty years of the International Court of Justice: essays in honour of Sir Robert Jennings (1996), 5.
} 
moral character, who possess the qualifications required in their respective countries for appointment to the highest judicial offices, or are jurisconsults of recognized competence in international law.

The requirement that judges are to be elected 'regardless of nationality' is qualified by two further provisions. First, Article 3 states that no two judges may be of the same nationality. Second, and more importantly, Article 9 provides that:

At every election, the electors shall bear in mind not only that the persons to be elected should individually possess the qualifications required, but also that in the body as a whole the representation of the main forms of civilization and of the principal legal systems of the world should be assured. [Emphasis added]

Article 9, which reproduces the corresponding provision of the Statute of the PCIJ, has become much more important today than the drafters of the PCIJ Statute could have imagined. They could not have foreseen the changes brought about by decolonization, which has resulted in a much more diverse and multicultural world, nor the emergence (and decline) of socialist and communist legal systems and the growth of Afro-Asian perspectives of international law.

In fact, while the Committee of Jurists responsible for presenting the draft Statute of the PCIJ to the Council of the League of Nations noted that the condition specified in Article 9 was imperative if the Permanent Court of International Justice is to be a real World Court for the society of all nations', it was also quite clear that it was closely linked to a concern to ensure a balance between the principle of equality of states and the demand by certain powerful nations to have a permanent seat on the bench. ${ }^{21}$ At the same time, the Committee sought to assuage the fear that one of the two perceived principal legal systems of the time would be imposed upon the other.

Indeed, the reference in Article 9 to the 'principal legal systems of the world' was, at that time, understood to be confined to the common law (or Anglo-Saxon) and civil (or continental) law systems of the western world. The Committee

${ }^{21}$ Société des Nations, Cour Permanente de Justice Internationale, Comité consultatif de Juristes, Procès-verbaux des séances du Comité 16 juin-24 juillet 1920 (1920), 108 (Mr Root). The same issue had been raised in different terms by Mr Hagerup, who underlined that les tentatives de la deuxième Conférence de la Paix, en vue de créer une Cour permanente, [avaient] échoué, [à cause de] l'impossibilité où l'on s'[était] trouvé de donner satisfaction, en même temps [au principe de l'égalité des Etats] et aux exigences de certaines grandes Puissances qui prétendaient exercer une influence prédominante sur la composition de la Cour', ibid, 103. 
of Jurists emphasised that what they envisaged was not the representation of particular schools of thought but rather that they wished to ensure a diversity of backgrounds in terms of legal education:

Ce qu'on a voulu ... c'est qu'au moment où un système de droit est engagé dans un litige, les autres systèmes de droit puissent en être immédiatement rapprochés, de manière à ce que ce soit vraiment l'esprit juridique de toutes les nations qui se tiennent en permanence au siège. ${ }^{22}$

Article 9 also refers to 'the main forms of civilization', which the Committee understood to be a broader concept, with a greater reach than 'legal systems'. As we have seen, the use of the term 'civilization' has a highly controversial legacy. It was deployed by colonial powers to distinguish their 'civilized nations' from the 'others' considered barbaric or savage. It was also used to justify the march of colonialism by reference to a 'civilizing mission'. However, the term could be viewed today as a simple metaphor for cultural diversity in a broad sense. The sweeping changes to the international community in the 1950s and 60s made the plea for equitable geographical representation on the bench more urgent than ever before, and the tipping point was perhaps reached in the South West Africa cases, ${ }^{23}$ the final outcome of which became highly controversial and ultimately prompted the readjustment of the Court's composition in order to remedy the underrepresentation of the newly independent states.

The election procedure itself (Article 4 of the Statute) plays an important part in determining the composition and in realising Article 9's objectives. The election procedure adopted by the Committee of Jurists was steeped in power politics: while the equality of states was emphasised, Lord Phillimore (UK) suggested that the 'material force' of the new Court was contingent on the presence of judges from the Great Powers and therefore the electoral process required a means to ensure a seat for each of the major powers. ${ }^{24}$ The solution was to submit the candidates, nominated by the national groups of the Permanent Court of Arbitration (PCA), to a double vote, before both the General Assembly and the Security Council. This was designed to ensure that both major

\footnotetext{
${ }^{22}$ Comité consultatif de Juristes, ibid, 710 (emphasis added).

${ }^{23}$ South West Africa (Ethiopia v South Africa), Second Phase, ICJ Reports 1966 p 6; see also South West Africa (Ethiopia v South Africa; Liberia v South Africa), Preliminary Objections, ICJ Reports $1962 \mathrm{p}$ 319.

${ }^{24}$ Comité consultatif de Juristes, above n 21, 105.
} 
powers-now the P5 of the Security Council-and the other nations (as a group) could either promote or try to block the election of a candidate, via the Security Council and the General Assembly respectively. This soothed both the concerns of the less powerful states, which called for sovereign equality, and those of the powerful ones, which were reluctant to submit to adjudication by a bench which did not include their nationals. ${ }^{25}$

In practice, the diversity mandated by Article 9 is fulfilled today by ensuring an equitable geographical distribution of seats. This distribution corresponds, by convention, to the composition of the Security Council, with five seats allocated to the permanent members of the Security Council and the remaining seats allocated across the five UN regional groups. At present, there are three judges from Africa, two from Latin America and the Caribbean, three from Asia, five from WEOG-the Western Europe and Other states Group-and two from Eastern Europe. Equitable geographical representation has also been endorsed by the founding instruments of other international tribunals; both the Rome Statute and the ITLOS Statute expressly provide for it, in addition to requiring that Judges come from the 'principal legal systems of the world'. ${ }^{26}$ During the drafting of the PCIJ statute, a Colombian proposal providing for the geographical representation of the different continents was in fact rejected; ${ }^{27}$ but we find ourselves today, to a great extent, in the situation originally envisaged by it.

The next question is, to what extent the diversity of the bench affects and influences the adjudicative process? How does a judge's background affect his performance on the bench? In this context, it must be emphasised that the judges of the ICJ do not represent their state or region, but strive to apply international law as determined either by the international community as a whole or by the states parties to a case. As stated by Mr Bourgeois during the debate of the Committee of Jurists:

\footnotetext{
${ }^{25}$ Mr Elihu Root, who was the US representative on the Committee of Jurists, proposed that the election of the Judges be entrusted jointly to the Assembly and Council. The practical effect of this idea was, according to him 'd'assurer aux petites Puissances la protection de leur intérêts par l'Assemblée, où elles sont en majorité, et aux grandes Puissances la protection des leurs par l'activité du Conseil où elles ont la prépondérance', Comité consultatif de Juristes, above n 21, 109.

${ }^{26}$ Rome Statute of the International Criminal Court, 17 July 1998, 2187 UNTS 3, Art 36(8); Statute of the International Tribunal for the Law of the Sea, UN Convention on the Law of the Sea, Annex VI, 10 December 1982, 1833 UNTS 3, Art 2.

${ }^{27}$ Documents au sujet des mesures prises par le Conseil de la SDN aux termes de l'Article 14 du pacte et de l'adoption par l'Assemblée du statut de la Cour permanente (1920) 72.
} 
[C] hosen not by reason of the State of which they are citizens, but by reason of their personal authority, of their past career, of the respect which attaches to their names known over the whole world. These judges will represent an ... international spirit which is the safeguard of [national] interests, within the limits of their legitimacy. ${ }^{28}$

The particularly collegial deliberation process of the Court-which involves all judges in the drafting of the decision until the final text of the judgment is agreed upon-facilitates a true exchange of ideas and approaches from diverse horizons and constitutes a working method suitable for accommodating different traditions. This was aptly described by Edward McWhinney in the following terms:

[The judges] interact among each other with the cross-currents in their legal education and professional formation operating to produce collegial decision-making that transcends conventional political-ideological, ethno-cultural and legal-systemic divisions. ${ }^{29}$

At the same time, as Judge Levi Carneiro stated in a dissenting opinion:

[It is] inevitable that every one of us in this Court should retain some trace of his legal education and his former legal activities in his country of origin. This is inevitable, and even justified, because in its composition the Court is to be representative of "the main forms of civilization and of the principal legal systems of the world".30

In sum, it may be said that the diversity on the bench ensures that judgments will be elaborated in a manner that takes into account different legal systems and, in the particular case of ad hoc judges, the Court may be fully apprised of issues which might be specific to a legal culture relevant to a case before it.

Finally, it should perhaps be mentioned that Article 9 has also been relied upon by judges to expand the sources of international law, enriching the law by reference to 'the wisdom of the world's several civilizations. ${ }^{31}$ In North Sea

\footnotetext{
${ }^{28}$ Comité consultatif de Juristes, above n 21, 7-8.

${ }^{29} \mathrm{E}$ McWhinney, The ICJ and the Western Tradition of International Law (1987), 138.

${ }^{30}$ Anglo-Iranian Oil Co. (United Kingdom v Iran), ICJ Reports 1952 p 93, 161 (Judge Levi Carneiro, diss).

${ }^{31}$ Gabčikovo-Nagymaros Project (Hungary/Slovakia), ICJ Reports 1997 p 7, 97 (Judge Weeramantry, sep op).
} 
Continental Shelf, Judge Ammoun identified the existence of a principle of equity in international law by surveying a wide range of 'the great legal systems of the modern world', ranging from the Roman jus gentium, the common law, Islamic law, Chinese law in harmony with the Marxist-Leninist philosophy, Soviet law, Hindu law, and the principles underlying the customary laws of Asian and African countries. $^{32}$ Later, Judge Tarazi, in his opinion in the Tehran Hostages case, referred to the existence, in Islamic law, of a principle of inviolability of foreign envoys, ${ }^{33}$ which was echoed by the Court in its judgment:

The principle of the inviolability of the persons of diplomatic agents and the premises of diplomatic missions is one of the very foundations of this long-established régime, to the evolution of which the traditions of Islam made a substantial contribution. ${ }^{34}$

According to a subsequent article by Judge Mosler, Judge Tarazi's contribution had 'strengthen[ed] the authority of the Court's statement that this principle formed part of the corpus of generally accepted principles of law.' ${ }^{35}$

Judge Weeramantry, who often referred to Article 9 and its importance, refused to accept the 'shallow cosmopolitanism which so often presents itself as embodying "the universal" 36 and sought to ground a universal international law on the wisdom and teachings of a broad range of civilizations, cultures and legal traditions. For him, the Court's Statute 'expressly opened a door to the entry of such principles into modern international law' by way of Article 9 and Article 38, paragraph 1(d) of the Statute. Article 9 in particular mandated the Court to 'search in all these traditions and legal systems for principles and approaches that enrich the law it administers. ${ }^{37}$

These notable views confirm that the best way in which universal international law can be further developed is by drawing upon the legal and ethical prin-

${ }^{32}$ North Sea Continental Shelf (Federal Republic of Germany/Denmark; Federal Republic of Germany/Netherlands), ICJ Reports 1969 p 3, 140 (Judge Ammoun, sep op).

${ }^{33}$ United States Diplomatic and Consular Staff in Tehran (United States of America v Iran), ICJ Reports 1980 p 3, 58 (Judge Tarazi, diss).

${ }^{34}$ United States Diplomatic and Consular Staff in Tehran (United States of America v Iran), ICJ Reports 1980 p 3, 40.

${ }^{35} \mathrm{H}$ Mosler, 'To What Extent Does the Variety of Legal Systems of the World Influence the Application of the General Principles of Law Within the Meaning of Article 38 (1)(c) of the Statute of the International Court of Justice', in TMC Asser Instituut, International Law and the Grotian Heritage (1985) 182-183.

${ }^{36}$ A Anghie, 'C. G. Weeramantry at the International Court of Justice' (2001) 14 LJIL 845, 846.

${ }^{37}$ Gabčikovo-Nagymaros Project, above n 31 (Judge Weeramantry, sep op) 109. 
ciples of numerous cultures and civilizations, as the Court has sometimes done in its judgments, and as the Judges mentioned above and many others, before or after them, did in their individual opinions.

\subsection{General principles of law}

Article 38, paragraph (1)(c) of the Statute was meant to constitute another route through which domestic legal systems could influence the content of international law. The objective here was not, however, to ensure that diverse legal traditions be taken into account, but to identify, as far as possible, certain principles which are common to all legal traditions. According to this Article, one of the sources of international law to be applied by the Court is 'the general principles of law recognized by civilized nations'.

Like the provisions examined earlier, Article 38, paragraph (1)(c) was borne out of a compromise between common law and civil law members of the Committee of Jurists of the League of Nations. However, they appear to have switched roles in the drafting of this provision, with some members adopting positions at variance with certain tenets of their own legal system. Thus, it was some of the members of the Committee of Jurists from the civil law tradition, where the role of the judge is usually limited to the application of the law as codified, who sought to grant a broad discretion to international judges to identify principles inherent to the 'legal conscience of civilized nations' (Baron Descamps of Belgium ${ }^{38}$ or 'in accordance with law, justice and equity' ( $\mathrm{Mr}$ Lapradelle of France). ${ }^{39}$ They were concerned with avoiding the risk of non liquet, whereby the judge might be forced to abstain from resolving a dispute if there was no governing rule under treaty or customary law. A type of rule was required which would enable the judge to 'complete' or 'fill gaps' in the law as necessary.

Meanwhile, the common law members-educated in a tradition where the judge participates in the law-making process through the creation of precedentsought to constrain the discretionary power of international judges, in keeping with a positivist and voluntarist position. Phillimore (UK) and Root (US) were concerned that the promotion of 'subjective conceptions of the principles of justice' and the open-ended nature of the provision would discourage states, which subscribed heavily to the voluntarist tradition, from submitting themselves to the Court's Statute. In their view, such states would not be 'disposed to accept the

\footnotetext{
${ }^{38}$ Comité consultatif de Juristes, above n 21, 306.

${ }^{39}$ Ibid, 295.
} 
compulsory jurisdiction of a Court which would apply principles, differently understood in different countries' or which would 'administer not merely law, but also what it deems to be the conscience of civilized people'. In order to encourage states to submit to the Court, they thought it necessary to limit judicial discretion and strictly circumscribe the sources of law. ${ }^{40}$

A compromise solution was proposed which provided for general principles but confined them to certain 'maxims of law' or principles that were derived from the general principles of municipal law, constituting those principles which are accepted by all nations in foro domestico.

The use of the adjective 'civilized' again warrants comment. It would appear that some of the drafters considered it superfluous and wanted to drop it. ${ }^{41}$ However, the pejorative colonialist connotation remains and, for this reason, the reference to civilized nations is viewed today as an archaic formula, 'entirely devoid of any particular meaning ${ }^{42}$ and 'tacitly dropped in today's literature. ${ }^{43}$ Indeed, in his separate opinion in North Sea Continental Shelf, Judge Ammoun affirmed that the anachronistic and unjustified formulation was the result of an oversight, because 'the general principles of law mentioned by Article 38, paragraph (1)(c), of the Statute, are nothing other than the norms common to the different legislations of the world', so that any other limitation would be arbitrary:

In view of this contradiction between the fundamental principles of the Charter, and the universality of these principles, on the one hand, and the text of Article 38, paragraph 1(c), of the Statute of the Court on the other, the latter text cannot be interpreted otherwise than by attributing to it a universal scope involving no discrimination between the members of a single community based upon sovereign equality. The criterion of the distinction between civilized nations and those which are allegedly not so has thus been

\footnotetext{
${ }^{40}$ Lord Phillimore, for example, referred to the 'serious differences of opinion [which] arose from the continental idea of justice; at the outset strict limitations are imposed on the judges, then through fear of restricting them too much they are given complete freedom within these limits. The English system is different: the judge takes an oath "to do justice according to law", ibid, 315. He added that the main issue was to limit the function of the international judge to the application of the law and to deny him the power to engage in law-making, ibid, 316.

${ }^{41}$ For Mr de Lapradelle, for example, 'qui dit droit dit civilisation', ibid, 335.

${ }^{42}$ A Pellet, 'Article 38', in Zimmermann et al (eds), The Statute of the International Court of Justice: a commentary ( $2^{\text {nd }}$ edn, 2012) 836.

${ }^{43}$ S Rosenne, Law and Practice of the International Court: 1920-2005 (4 $4^{\text {th }}$ edn, 2006) 1602.
} 
a political criterion-power politics - and anything but an ethical or legal one. ${ }^{44}$

The Court, notwithstanding a plethora of doctrinal debate, has generally eschewed reference to Article 38, paragraph (1)(c). As Judge Gaja has observed, the Court is 'understandably reluctant to apply general principles in a way that would imply a selection among municipal rules and thus the use of a large amount of discretion in finding the more appropriate rule'. ${ }^{45}$ Pellet also notes that it 'has been expressly mentioned only four times in the entire case law of the Court since 1922 and each time, it has been ruled out for one reason or another. ${ }^{46}$

The Court often uses expressions such as 'generally recognized principle of procedural law'; 'an established rule of law'; or 'general and well-recognized principles'. For example, in Corfu Channel, the Court found that 'indirect evidence is admitted in all systems of law, and its use is recognized by international decisions' and consequently allowed circumstantial evidence to be admitted to the Court. ${ }^{47}$ In the UN Administrative Tribunal opinion, the Court held that 'according to a well-established and generally recognized principle of law, a judgment rendered by such a judicial body is res judicata and has binding force between the parties to the dispute. ${ }^{48}$ Later, in the Nuclear Tests cases, the Court described the principle of good faith as 'one of the basic principles governing the creation and performance of legal obligations. ${ }^{49}$ These are all principles determined by the Court to be fundamental legal precepts inherent to and necessary for the operation of the international legal order.

In practice, the Court has surmounted the difficulties inherent in the application of Article 38 (1)(c) by taking inspiration from principles that are also present in domestic systems, and adapting them to the body of international law such that they become its own creation. At the same time, the role of Article $38(1)(c)$ has changed over the years. Today it is more common to refer to general principles of international law rather than general principles derived from foro domestico and transposed to the international plane. These are principles inherent

\footnotetext{
${ }^{44}$ North Sea Continental Shelf, above n 32, 134 (Judge Ammoun, sep op).

${ }^{45}$ G Gaja, 'General Principles of Law', in Max Planck Encyclopedia of Public International Law, <http://opil.ouplaw.com/view/10.1093/law:epil/9780199231690/law-9780199231690-e1410> [accessed 15 August 2013, restricted to subscribers].

${ }^{46}$ Pellet, above n 42, 833.

${ }^{47}$ Corfu Channel (United Kingdom v Albania), ICJ Reports 1949 p 4, 18.

${ }^{48}$ Effect of Awards of Compensation Made by the United Nations Administrative Tribunal, Advisory Opinion, ICJ Reports 1954 p 47, 53.

${ }^{49}$ Nuclear Tests (Australia v France), ICJ Reports 1974 p 253, 268.
} 
to and derived from the international legal system itself, such as those contained in the United Nations Charter as purposes and principles governing the conduct of all states and codified in the 'Declaration on Principles of International Law concerning Friendly Relations and Co-operation among States in accordance with the Charter of the United Nations', which was adopted by the General Assembly in its Resolution 2625 (XXV). ${ }^{50}$

\subsection{Separate and dissenting opinions}

Article 57 of the Statute of the Court states that:

If the judgment does not represent in whole or in part the unanimous opinion of the judges, any judge shall be entitled to deliver a separate opinion.

Article 95 clarifies that any Judge may attach an individual opinion 'whether he dissents from the majority or not'. In addition, this provision allows a judge to make a declaration, in which he records his position without stating his reasons in detail. Dissenting and separate opinions have become a significant feature in the Court's jurisprudence: in the 641 decisions (Judgments, Orders and Advisory Opinions) rendered by the Court by mid-2013, over 1,146 individual opinions or declarations were appended. Moreover, it may be said that they constitute the building blocks of future approaches and analysis by the Court as a whole and often inspire its subsequent decisions.

The inclusion of dissenting opinions in the Statute was subject to much debate and was not a foregone conclusion. Dissenting opinions are strongly rooted in the common law tradition; while they are almost unknown in the civil law tradition where courts deliver collective judgments. In light of this dichotomy, the provenance of Article 57 is, in fact, quite surprising.

The 1899 Hague Convention for the Pacific Settlement of International Disputes provided that arbitrators could record their disagreement with an award, without being able to provide reasons. However, by the second Hague Convention in 1907, opponents of dissenting opinions prevailed, and any reference to dissenting opinions was omitted. ${ }^{51}$

In 1920, the Committee of Jurists proposed to allow judges to indicate their dissent but expressly forbade them from stating the reasons for the opinion. $\mathrm{Mr}$

\footnotetext{
$\overline{50}$ GA Res 2625 (XXV), 24 October 1970.

${ }^{51}$ R Hofmann \& T Laubner, 'Article 57', in Zimmermann et al, above n 42, 1385.
} 
Fromageot, the French proponent of the provision, argued that 'anything that might give umbrage to States must be avoided' and that it might impede the independence of national judges before their governments. ${ }^{52}$ More surprisingly, the French proposal received the support of the British and American members. Meanwhile, other members trained in the civil law system-such as the Brazilian, Italian and Japanese members-all supported the publicity of the dissenting opinions, but they were in a minority.

However, when the draft scheme was presented to the Council of the League of Nations, it was the French representative on the Council, Mr Leon Bourgeois, who proposed an amendment to allow fully reasoned dissenting opinions to be appended to decisions, in order to ensure that 'the play of the different judicial lines of thought would appear clearly. ${ }^{53}$ Notwithstanding the opposition of the Dutch and Italian members, who found the idea 'foreign to Continental procedure', the proposal was adopted.

In light of this history, the allowance made in the Statute of the Court for dissenting opinions should not be seen as a feature of the common law, but rather as another means to ensure the influence of diversity of legal traditions so that the principal legal systems of the world are expressed in the Court's jurisprudence.

The objectives and reasons for allowing individual opinions at the ICJ are in fact closely aligned with the aims of Article 9 of the Statute. Judge Jennings argued that the presence of individual opinions was essential to ensure that all views are accounted for, which is an important guarantee of the universality of international adjudication at the ICJ. ${ }^{54}$ Similarly, Judge Ammoun stated that individual opinions allow us to 'ascertain the extent to which [a judgment] expresses the opinion of the Court, and what objections judges no less qualified than those who supported it were able to bring against it'; for him, the authority of those opinions was also derived from the fact that the judges were elected, according to Article 9, to represent the main forms of civilization and principal legal systems of the world. ${ }^{55}$

Today, many international tribunals provide for individual opinions (ECHR, IACHR, ACHPR, ITLOS, ICTY, ICTR). However, some notable outliers exist. The

\footnotetext{
${ }^{52}$ Quoted in M O Hudson, The Permanent Court of International Justice 1920-1942: A Treatise (1943), 206.

${ }^{53}$ Documents, above n 27, 50.

${ }^{54}$ R Y Jennings, 'The Internal Judicial Practice of the International Court of Justice' (1988) 59 BYIL 31, 42-44.

${ }^{55}$ Barcelona Traction, Light and Power Company, Limited (Belgium $\mathrm{v}$ Spain), Second Phase, ICJ Reports 1970 p 3, 317 (Judge Ammoun, sep op).
} 
WTO Dispute Settlement Body allows only anonymous dissenting opinions. The Court of Justice of the European Union does not allow for dissenting opinions, delivering only a single judgment (although a healthy dialectic between the opinion of the assigned Advocate-General and that of the Court often increases legal diversity). More recently, the ILC's initial proposal for an International Criminal Court Statute precluded individual opinions for fear that a division of the Court might undermine the authority of the judgment. ${ }^{56}$ However, this proposal was rejected and Article 45 of the Rome Statute now provides for dissenting opinions.

\section{Conclusions}

Having recognised the importance of diverse legal traditions to the universality of international law, I wish to conclude with some reflections on the future of diversity within the international legal order. Are common and civil law traditions destined to remain the predominant legal systems influencing international law? Can we envisage an expansion of the sources of international law to accommodate other legal cultures or visions?

I would like to go back for a moment to what I said earlier, when I referred to Third World scholars who-in reaction to the Euro-centric views of western scholars on international law and apparently tired of all the talk about international law having developed only in Europe-wrote about the contributions of Asia and Africa to international law. In this regard, I must say that, in the same way that I find fault with the doctrines of Westlake, Fauchille, Oppenheim, and other European positivists of the $19^{\text {th }}$ and early $20^{\text {th }}$ century for their parochial and Euro-centric views which equated the public law of Europe with international law, I also find the 'contributionist' theories of Third World scholars rather unsatisfactory.

In particular, I find somewhat inadequate the writings of those Third World scholars who, for example, contend that pacta sunt servanda was also found in Asian or African legal traditions, or point to the practice of the 'silent trade' and diplomatic exchanges between African sovereigns and European merchants to demonstrate the African contribution to international law. This is inadequate for two reasons. First, while there is no doubt that different systems of public law and inter-state practices existed in various parts of the world and not only

${ }^{56}$ Commentary to the Draft Code of Crimes against the Peace and Security of Mankind, ILC Ybk 1994/II(2) 26, Art 45, para 5. 
in Europe, and in some cases even much earlier than in Europe, ${ }^{57}$ it cannot be denied that $19^{\text {th }}$ century Europe exercised a hegemonic influence on international law and that European positivist scholars invented constitutive recognition and the standard of civilization, first, to exclude others from the magic circle of the so-called club of 'civilized nations', and later to impose European public law concepts and rules on the rest of the world. It could perhaps be added that they were temporarily successful in their imposition of these concepts-although, crucially, this transformation from European public law to international law was not the end of the story, as the subsequent universalisation of international law brought about fundamental changes both to the scope and content of the law.

Secondly, I believe that a more interesting and productive approach is to consider what impact and positive contribution legal traditions have made to international law by applying a value-added test. The importance of this approach lies in the fact that international law will be truly universal only if it can, in the words of Robert Jennings, 'comprehend within itself the rich diversity of cultures, civilizations and legal traditions. ${ }^{58}$ We must therefore identify how diverse cultures and traditions have added new legal precepts to these old concepts and changed them for the better.

By way of illustration, I will point to a few examples of innovative principles and rules based on the legal traditions of Third World states that have made their way-or are in the process of making their way-into international law, thus representing an added value to international law, making it more reflective of universality through incorporation of diverse values. It must, however, be recognised that these value-adding principles and rules postdate the decolonization of the Third World, and therefore have resulted from the active participation of formerly colonized countries in the development of international law after their independence. Needless to say, much more research will be required to identify similar concepts and principles fulfilling the value-added test in the pre-colonial period. This is particularly true with reference to African and Asian countries, given that the colonial period constituted the parenthesis within which the public law of Europe transformed itself, mostly because of the phenomena of colonialism and imperialism, into international law.

\footnotetext{
${ }^{57}$ A good example is the treaty inscribed in the Pan Water Vessel of San exhibited in the National Palace Museum of Taipei, Taiwan (China), which records the settlement of a territorial dispute between two adjacent feudal states of San and Ze (late Western Zhou Dynasty, circa 9th century to $771 \mathrm{BC}$ ), giving a full account of the joint survey by all parties involved of the lands to be surrendered as well as a map of such lands and Ze's oath-taking scene.

${ }^{58}$ Jennings, above $\mathrm{n} 54,49$.
} 
In the post-colonial period, these concepts and principles include, for example, in the case of Latin America, the concept of local custom and the principle of uti possidetis juris, both of which have been recognised in judgments of the International Court of Justice. ${ }^{59}$ I could also add the notion of patrimonial sea, which partly inspired the corresponding African concept of Exclusive Economic Zone that was incorporated into UNCLOS following active participation of African states at the Third United Nations Conference on the Law of the Sea (1973-1982) and is now recognised as a customary norm of international law.

In the case of Africa in the post-colonial period, one could point to the recognition of collective rights in conventional instruments and the gradual recognition, at the impetus of Afro-Asian countries in the UN, of the right of peoples to self-determination not only as a principle, but as a right. This has resulted in the recognition of 'peoples' as bearers of rights and obligations in international law. ${ }^{60}$ I could add the expanded concept of refugees under international law, introduced by the 1969 OAU Convention on Refugees; ${ }^{61}$ the conventional codification of the right to development, the right to a clean environment, or other collective rights in treaties concluded among African states; ${ }^{62}$ as well as the innovative principles and rules underlying the Kampala Convention on displaced persons ${ }^{63}$ and the African Charter on Democracy, Elections and Governance. ${ }^{64}$ Even more interesting is the right of a regional organization to intervene forcefully in its member states in certain circumstances

\footnotetext{
${ }^{59}$ As to local custom, see Asylum (Colombia/Peru), ICJ Reports 1950 p 266, 276; Right of Passage over Indian Territory (Portugal v India), ICJ Reports $1960 \mathrm{p} 6$ 6, 39. As to uti possidetis juris, see Frontier Dispute (Burkina Faso/Republic of Mali), ICJ Reports 1986 p 554, 565; Land, Island and Maritime Frontier Dispute (El Salvador/Honduras: Nicaragua intervening), ICJ Reports 1992 p 351, 386-388; Frontier Dispute (Burkina Faso/Niger), Judgment of 16 April 2013 (Judge Yusuf sep op).

${ }^{60}$ GA Res 1514(XV), 14 December 1960; GA Res 2625 (XXV), 24 October 1970.

${ }^{61}$ OAU Convention Governing the specific aspects of refugee problems in Africa, 10 September 1969, 1001 UNTS 45, Art 1(2) (In addition to those individually persecuted, " $t$ the term "refugee" shall also apply to every person who, owing to external aggression, occupation, foreign domination or events seriously disturbing public order in either part or the whole of his country of origin or nationality, is compelled to leave his place of habitual residence in order to seek refuge in another place outside his country of origin or nationality').

${ }^{62}$ See African Charter on Human and Peoples' Rights, 27 June 1981, CAB/LEG/67/3 rev. 5, Art 19-24.

${ }^{63}$ African Union Convention for the Protection and Assistance of Internally Displaced Persons in Africa, 23 October 2009, <http://www.au.int/en/content/african-union-conventionprotection-and-assistance-internally-displaced-persons-africa > [accessed 15 August 2013].

${ }^{64}$ African Charter on Democracy, Elections and Governance, 30 January 2007, <http://www.au.int/en/content/african-charter-democracy-elections-and-governance> [accessed 15 August 2013].
} 
such as genocide, crimes against humanity and war crimes, which is now recognised under the constitutive Act of the African Union. ${ }^{65}$

In my view, an important vector of diversity in the future of international law will be that of regional diversity. The application, interpretation and creation of international law by regional organizations and regional courts are likely to provide a key impetus in the development and evolution of international law. These regional forums can be likened to the 'laboratories' of federal systems: experimentation and legal innovation often occur at the decentralised level, where legislators (in this case, international legislators) are closer to their constituents. From there, effective legal principles and rules and best practices can be diffused to and copied by other systems and-eventually and progressively-seep into the fabric of universal international law. Therefore, regional diversity is likely to be an engine for the development of international law in the years to come.

Africa represents an excellent example of the potential contribution regional diversity can make to general international law. In recent years, the African Union assumed an important role in legal production and codification. Importantly, many of these African conventions constitute considerable improvements in relation to the global international law instruments. Take, for example, the protection of peoples' rights in Africa. The African Charter of Human and Peoples' Rights not only expressly recognises the rights of peoples within the Charter, it dedicates six articles to peoples' rights, extending from the right to self-determination, the right to natural resources, the right to economic, social and cultural development, the right to peace and security and the right to a safe and healthy environment. ${ }^{66}$ This recognition of peoples' rights is unprecedented and unmatched by any other multilateral human rights instrument. Moreover, the African Commission, a quasi-judicial body responsible for monitoring rights protection under the Charter, became the first such body to define the concept of 'peoples' for the purposes of the African Charter, and to apply it to concrete cases brought before it. ${ }^{67}$ There is reason to hope that the best aspects of these regional developments will begin to pervade and influence general international

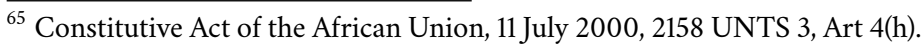

${ }^{66}$ See above $\mathrm{n} 62$.

${ }^{67}$ See African Commission on Human and People's Rights, cases 155/96: Social and Economic Rights Action Center (SERAC) and Center for Economic and Social Rights (CESR) v Nigeria, 13-27 October 2001, para 40; and 276/2003: Centre for Minority Rights Development (Kenya) and Minority Rights Group International on behalf of Endorois Welfare Council v Kenya, 11-25 November 2009, paras 145-162.
} 
law and gradually turn into global standards.

Furthermore, the influence of regional adjudicative tribunals and quasijudicial bodies on general international law is beginning slowly to take hold. While the ICJ is often reluctant to cite the jurisprudence of regional tribunals or quasi-judicial bodies, the Diallo case marked a significant departure from this trend. ${ }^{68}$ The Court, when determining the legality of Diallo's detention and expulsion under Article 12 (4) of the African Charter on Human and Peoples' Rights, took note of the fact that its finding was consonant with the relevant precedents of the African Commission on Human and Peoples' Rights. ${ }^{69}$ Furthermore, the Court referred to the interpretation by the European Court of Human Rights and the Inter-American Court of Human Rights of analogous provisions under their regional instruments in support of its conclusion. ${ }^{70}$

In light of the above, it may be concluded that your conference's positive outlook on the endurance of the diversity of legal traditions appears justified. In addition to domestic legal traditions, we note the growing importance of regional traditions as the role of regional organizations in international law-making keeps acquiring more importance. These regional traditions are likely to provide fresh impetus to the development and evolution of universal international law as some of their innovative legal rules, principles and practices are gradually transferred to the universal level, and as international judicial bodies find inspiration in those rules and practices in resolving international disputes.

\footnotetext{
${ }^{68}$ Ahmadou Sadio Diallo (Republic of Guinea v Democratic Republic of the Congo), ICJ Reports $2010 \mathrm{p}$ 639.

${ }^{69}$ Ibid, 664.

${ }^{70}$ Ibid.
} 